\title{
EFEECT OF DIFFERENT PRIMING METHODS IN RICE (ORYZA SATIVA)
}

\author{
R. Subedi ${ }^{1}$, B.K. Maharjan ${ }^{1}$ and R. Adhikari ${ }^{2}$
}

\begin{abstract}
Good germination of rice is considered critical for the plant life cycle. A laboratory experiment was conducted in IAAS, Lamjung campus, Sundarbazar tostudy the effect of different priming methods in rice. The experiment was done in completely randomized design using 12 treatmentsreplicated thrice. The treatments consisted;Control (No priming), Hydro priming (soaking of seeds in distilled water for $72 \mathrm{hrs}$ ), PEG6000 - 5\% and $10 \% \mathrm{CaCl}_{2}-0.5 \%$ and $1 \% \mathrm{KCl}-2 \%$ and $4 \% \mathrm{KNO}_{3}-1 \%$ and $2 \%$ and $\mathrm{NaCl}-1.8 \%$ and $3.6 \%$ where seeds were soaked for 12 hours followed by 12 hours drying. Both hydro priming and PEG improved germination energy, germination index, germination speed, radical length, and plumule length. The effect due to varied doses were not observed in the priming substances except PEG 6000, where PEG6000 - 5\% was better as compared to PEG - 10\% in overall observations.
\end{abstract}

Keywords: Halopriming, hydropriming, osmopriming, polyethylene glycol (PEG), seed priming.

\section{INTRODUCTION}

Rice (Oryza sativa L.) is a major food crop for the people of Asia; nearly $90 \%$ of the world's rice is produced and consumed in this region. Germination and seedling establishment are critical stages in the plant life cycle. Cereal production is widely limited by poor seed germination and crop establishment (Jones and Wanbi, 1992). Germination tends to be irregular and can extend over long periods particularly in drought-prone environments (Bougne et al., 2000). The resulting poor crop germination leave gaps in the canopy, which are rapidly filled by vigorously growing weeds at the onset of the short rainy season which compete with the crop plants for light, water and nutrients (Kropff and Van Laar, 1993). Accelerating and homogenizing the germination process is a prerequisite for a good crop establishment, the efficient use of resources, and eventually to increase yields (Harris, 1996).

Seed priming can be low cost technology which can replace the traditional transplanting method which takes more labour force and longer duration to maturity compared to primed seed cultivation. Crop failure may occur reducing crop productivity if poor seed germination behavior occurs in field crop (Ghiyasi et. al. , 2008) which can be addressed by priming treatment leading to better germination and establishment in any crop (Basra et. al., 2005; Ghiyasi et. al., 2008). Rapid seed germination and stand establishment are critical factors for crop production under stress conditions. In many crop species, seed germination and early seedling growth are the most sensitive stages to stresses. Seed

\footnotetext{
${ }^{1}$ Institute of Agriculture and Animal Science, Lamjung Campus,Sundarbazar, Lamjung

${ }^{2}$ Plant Protection Officer, Plant Qurantine Checkpost, Tribhuvan International Airport, Kathmandu,Nepal
} 
priming is known as the seed treatment which improves seed performance adverse under stressful environmental conditions (Ashraf and Foolad, 2005). Seed priming is defined as pre sowing treatments in water (hydropriming) or in an osmotic solution (osmopriming) that allows seed to imbibe water to proceed to the first stage of germination, but prevents radicle protrusion through the seed coat. Presowing treatment with inorganic salts (halo priming) not only promotes seed germination of most crops, but also stimulates later growth, metabolic processes and, hence, ultimate crop yield. Seed priming stimulates a different biochemical changes in the seed that are essential to initiate the germination process e.g. water imbibition, breaking of dormancy, activation of certain enzyme etc. (Ajour et al., 2004). Primed seeds emerged 12h earlier than non primed seeds (Dell-Aquila and Tritto, 1990). This is due to increase in activity of enzymes such as amylase, protease and lipase which have great role in breakdown of macromolecules for growth and development of embryo that ultimately resulted in early and higher seedling emergence. The most important priming treatments are osmopriming, halopriming and hydro priming.

\section{MATERIALS AND METHODS}

The experiment was conducted in Agronomy lab of Lamjung Campus of Institute of Agriculture and Animal Sciences, Sundarbazar, Lamjung. Sookha dhan -2 variety of rice was used in the experiment. The experiment was carried out in completely randomized design consisting of 12 treatments replicated 3 times. The treatments consisted of priming with different priming substances followed by re-drying for 12 hours. The treatments used were Control (No Priming), Hydro priming (soaking of seeds for $72 \mathrm{hrs}$ ), PEG6000 5\% and 10\%, $\mathrm{CaCl}_{2}-0.5 \%$ and $1 \%, \mathrm{KCl}-2 \%$ and $4 \%, \mathrm{KNO}_{3}-1 \%$ and $2 \%$ and $\mathrm{NaCl}-1.8 \%$ and $3.6 \%$ for 12 hours followed by 12 hours drying. Observations were taken regularly for germination and counting was done regularly until final germination was recorded. For radical and plumule length reading was taken in $5^{\text {th }}$ day with a measuring scale.

All the recorded data were tested for normality and homogeneity and analyzed using SPSS. The mean separation was done using LSD (at $5 \%$ level of significance).

\section{RESULTS AND DISCUSSION} GERMINATION ENERGY(GE)

The results shows that there was significant difference between different priming methods on GE (Table 1). Hydro priming, $\mathrm{KNO}_{3}-2 \%$ and PEG - $5 \%$ showed significantly higher GE than control and $\mathrm{NaCl}-3.6 \%$. However, no any priming substances used brought significant alterations to GE when used in varied levels.

\section{GERMINATION INDEX(GI)}

All the priming methods (hydro priming, $\mathrm{KNO}_{3}, \mathrm{KCl}, \mathrm{NaCl}, \mathrm{PEG}$ and $\mathrm{CaCl}_{2}$ ) showed significantly higher germination index than control at both the levels but in case of $\mathrm{KNO}$, $\mathrm{KCl}$, and $\mathrm{CaCl2}$, there was statistical similarity between the varied doses (Table. 1). However, significant decrease in germination index was observed with increase in level of $\mathrm{NaCl}$ and PEG. 


\section{GERMINATION SPEED(GS)}

Hydro priming, $\mathrm{KCl}-1 \%, \mathrm{KNO}_{3}-2 \%, \mathrm{NaCl}-1.8 \%, \mathrm{PEG}-5 \%$ and $\mathrm{CaCl}_{2}-1 \%$ showed higher $\mathrm{GS}$ than control and $\mathrm{NaCl}-3.6 \%$. There was statistical similarity among varied doses of all chemicals except $\mathrm{NaCl}$, where increase in salt concentration significantly reduced the GS.

Table 1. Effect of different methods of priming on rice germination indices in Sundarbazar, Lamjung during 2014.

\begin{tabular}{|c|c|c|c|c|c|c|}
\hline Treatment & $\begin{array}{l}\text { Germination } \\
\text { energy (GE) }\end{array}$ & $\begin{array}{c}\text { Germination } \\
\text { index (GI) }\end{array}$ & $\begin{array}{l}\text { Germination } \\
\text { speed (GS) }\end{array}$ & $\begin{array}{l}\text { Radical } \\
(\mathrm{cm})\end{array}$ & $\begin{array}{l}\text { Plumule } \\
(\mathrm{cm})\end{array}$ & $\begin{array}{l}\text { Radical:plumule } \\
\text { ratio }(\mathrm{cm})\end{array}$ \\
\hline T1 (control) & $90^{\mathrm{b}}$ & $6.556^{\mathrm{d}}$ & $94.54^{\mathrm{b}}$ & $3.860^{c}$ & $1.467^{c}$ & 2.676 \\
\hline T2 (hydro priming) & $100^{\mathrm{a}}$ & $9.361^{\mathrm{a}}$ & $100^{a}$ & $5.373^{\mathrm{ab}}$ & $2.453^{\mathrm{a}}$ & 2.302 \\
\hline T3 (KCl@1\%) & $95^{\mathrm{ab}}$ & $9.167^{\mathrm{ab}}$ & $100^{\mathrm{a}}$ & $4.680^{\mathrm{bc}}$ & $1.940^{\mathrm{b}}$ & 2.467 \\
\hline T4 (KCl@2\%) & $95^{\mathrm{ab}}$ & $8.361^{\mathrm{bc}}$ & $98.25^{\mathrm{ab}}$ & $5.033^{b}$ & $1.720^{\mathrm{bc}}$ & 2.924 \\
\hline T5 ( $\left.\mathrm{KNO}_{3} @ 2 \%\right)$ & $98.33^{\mathrm{a}}$ & $9.028^{\mathrm{ab}}$ & $100^{\mathrm{a}}$ & $5.273^{\mathrm{a}}$ & $1.820^{\mathrm{bc}}$ & 2.910 \\
\hline T6 (KNO 3 @4\%) & $95^{\mathrm{ab}}$ & $8.694^{\mathrm{ab}}$ & $98.33^{\mathrm{ab}}$ & $4.867^{\mathrm{b}}$ & $1.887^{\mathrm{b}}$ & 2.582 \\
\hline T7 (NaCl@ 1.8\%) & $93.33^{\mathrm{ab}}$ & $9.139^{\mathrm{ab}}$ & $100^{\mathrm{a}}$ & $5.387^{\mathrm{ab}}$ & $2.047^{a b}$ & 2.637 \\
\hline T8 (NaCl@3.6\%) & $83.33^{\mathrm{b}}$ & $7.694^{c}$ & $90.93^{\mathrm{b}}$ & $4.200^{\mathrm{bc}}$ & $1.467^{c}$ & 2.939 \\
\hline T9 (PEG6000@5\%) & $100^{\mathrm{a}}$ & $9.333^{\mathrm{a}}$ & $100^{\mathrm{a}}$ & $5.940^{\mathrm{a}}$ & $2.433^{\mathrm{a}}$ & 2.450 \\
\hline T10 PEG6000@10\%) & $93.33^{\mathrm{ab}}$ & $8.500^{\mathrm{b}}$ & $96.58^{\mathrm{ab}}$ & $4.400^{\mathrm{bc}}$ & $1.680^{\mathrm{bc}}$ & 2.718 \\
\hline T11 ( $\left.\mathrm{CaCl}_{2} @ 0.5 \%\right)$ & $96.67^{\mathrm{ab}}$ & $8.333^{\mathrm{bc}}$ & $96.39^{\mathrm{ab}}$ & $5.127^{\mathrm{ab}}$ & $1.927^{\mathrm{b}}$ & 2.668 \\
\hline 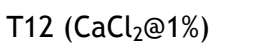 & $93.33^{\mathrm{ab}}$ & $8.944^{\mathrm{ab}}$ & $100^{\mathrm{a}}$ & $4.580^{\mathrm{bc}}$ & $1.527^{\mathrm{bc}}$ & 3.041 \\
\hline $\mathrm{N}$ & 94.44 & 8.593 & 97.92 & 4.893 & 1.864 & 2.693 \\
\hline LSD & 8.061 & 0.7214 & 5.110 & 0.8523 & 0.4201 & (ns) \\
\hline CV & $5.0 \%$ & $5.0 \%$ & $3.1 \%$ & $10.3 \%$ & $13.4 \%$ & $18.6 \%$ \\
\hline
\end{tabular}

ns: non significant at $p<0.05$. Different letters indicate significant difference at $p<0.05$.

\section{RADICAL LENGTH}

Hydro priming, $\mathrm{KCl}-2 \%, \mathrm{KNO}_{3}-2 \%$ and $4 \%, \mathrm{NaCl}-1.8 \%, \mathrm{CaCl}_{2}-0.5 \%$ and PEG - 5\% resulted higher radical length than control. Different levels of $\mathrm{KCl}, \mathrm{NaCl}$ and $\mathrm{CaCl}_{2}$ were statistically similar (Table 1) but variation among different doses were observed in $\mathrm{KNO}_{3}$ and PEG, where increase in level of both chemicals significantly decreased the radical length.

PLUMULE LENGTH

Hydro priming, Nacl $-1.8 \%$ and PEG - $5 \%$ resulted significantly higher plumule length than other priming methods. There was no sigmificant difference between different levels of $\mathrm{KCL}, \mathrm{KNO}_{3}$, and $\mathrm{CaCl}_{2}$ (Table 1) but among various level of $\mathrm{NaCl}$ and PEG there was significant difference which indicates that with increase in levels of both chemicals there is decrease in plumule length. 


\section{RADICAL TO PLUMULE RATIO}

There was no significant difference between for root:shoot ratio because there was corresponding growth of radical and plumule among various priming methods.

Pre-germination metabolic activities are completed during seed priming, making the seed ready for germination compared with unprimed seeds (Sadeghi et al., 2011). The embryo expands and compresses the endosperm due to effect of priming (Liptay and Zaiffa, 1993). Due to this compression force of the embryo and hydrolytic activities on the endosperm cell wall, that deforms the tissues that have lost their flexibility upon dehydration (Lin et al., 1993), producing free space and facilitating root protrusion after rehydration. Due to faster water uptake and earlier initiation of metabolic processes, there is fastest rate of germination obtained by seed priming. Seeds would be simultaneously subjected to processes of repair and deterioration and force between the two determines the success or failure of the treatment due to which early seed germination occurs during priming (McDonald, 2000). Good germination and emergence is the key to control stand establishment. Seed hydration of wheat, barley and oats seeds improved the uniformity of seedling emergence (Kibite and Harker, 1991). Hydro priming enhanced seedling establishment and early vigor of upland rice, maize and chickpea, resulting in faster development, earlier flowering and maturity and higher yields (Harris et al.,1999). There is rapid and uniform seed germination of several cereal crops specially rice as seed priming was done (Basra et al. , 2005; Jie et al. , 2002).

Cell growth and division play a great role in early stages of germination and seedling growth this needs the transmission of necessary nutrients like soluble sugars and low weight proteins from storage organs of seed to growth sites for transpiration (Bewley and Black, 1994). Significant improvement in radicle and plumule length may be attributed to earlier germination induced by primed over un-primed seeds (Farooq et al., 2005), which resulted in vigorous seedlings with more root and shoot length than the seedlings from unprimed seeds.

\section{CONCLUSION}

In many rainfed areas, germination and subsequent seedling growth can be inhibited by adverse conditions in the field. Priming is helpful in reducing the risk of poor stand establishment under a wide range of environmental conditions. Hydro priming and PEG6000 - 5\% resulted better performences compared to other priming methods for different germination indices in the experiment. Therefore, it is advisable to practice hydro priming or priming with PEG6000 - 5\% as a successful technique for increasing and hastening of seed germination and better crop stand.

\section{ACKNOWLEDGEMENT}

We would like to show our sincere gratitude to IAAS, Lamjung Campus, lab assistants and colleagues who directly or indirectly helped us with our research activities. 


\section{REFERENCES}

Ajour, A. 2004. Seed priming enhances germination and seedling growth of barley under conditions of $P$ and Zn deficiency. J. Plant Nutr. Soil Sci. 167: 630-636.

Ashraf, M. and M.R. Foolad, 2005. Pre-sowing seed treatment - a shotgun approach to improve germination, plant growth and crop yield under saline and non-saline conditions. Adv. in Agro. 88: 223-271.

Basra, S.M.A., I. Afzal, A.R. Rashid and M. Farooq. 2005. Pre-sowing seed treatment to improve germination and seedling growth in wheat (Triticum aestivum L.) seeds. Pak. J. Arid Agri. 5: 1116.

Bewley, J.D. and M. Black. 1994. Seeds physiology of development and germination. $2^{\text {nd }}$ edition. New York: Plenum Press.

Bougne, S., C. Job and D. Job. 2000. Sugarbeet seed priming: solublization of the baisc subunit of 11S globulin in individual seeds. Seed Sci. Res. 10: 153-161.

Dell-Aquila, A. and V. Tritto. 1990. Ageing and osmotic priming in wheat seeds: Effects upon certain components of seed quality. Ann. Bot. 65: 21-26.

Farooq, M., S.M.A. Basra, K. Hafeez and N. Ahmad, 2005. Thermal hardening: a new seed vigor enhancement tool in rice. J. Integr. Plant Biol. 47: 187-193.

Ghiyasi, M., A.S. Abbasi, M. Tajbakhsh, R. Amirnia and H. Salehzade. 2008. Effect of osmopriming with polyethylene glycol (8000) on germination and seedling growth of wheat (Triticum aestivum L.) seeds under salt stress. Res. J. Bio. Sci. 3(10): 1249-1251.

Harris, D. 1996. The effect of manure, genotype, seed priming, depth and date of sowing on the emergence and early growth of Sorghum bicolor (L.) Moench. in semi-arid Botswana. Soil Till. Res. 40: 73-88.

Harris, D., A. Joshi, P.A. Khan, P. Gothkar and P.S. Sodhi. 1999. On -farm seed priming in semi-arid agriculture: development and evaluation in maize, rice and chickpea in India using participatory methods. Expl. Agric. 35:15-29.

Jie, L., L. Gong Sheo, F. Dong Mei and W. Fang Enhua. 2002. Effect of PEG on germination and active oxygen metabolism in wild rye seed. Intl. J. Agri. Res. Rev. 2(1): 7-11.

Jones, M.J. and A. Wanbi. 1992. Site- factor influence on barley response to fertilizer in on-farm trials in northern Syria: descriptive and predictive models. Exp. Agri. 28: 63-87.

Kibite, S. and K.N. Harker. 1991. Effect of seed hydration on agronomic performances of wheat, barley and oats in central Alberta. Plant Sci. 71: 515-518.

Kropff, M.J. and H.H. Van Laar. 1993. Modeling crop- weed interactions. CAB International, Wallingford, U.K. 272pp.

Lin, Y., W.J. Van Der Burg, J.W. Aartse, R.A. Van Zwol, H. Jalink and Bino. 1993. X-ray studies on changes in embryo and endosperm morphology during and inhibition of tomato seeds. Seed Sci. Res. 3: 171-178.

Liptay, A. and N. Zariffa. 1993. Testing the morphological aspects of polyethylene glycol primed tomato seeds with proportional odds analysis. Hort. Sci. 28: 881-883.

McDonald, M.B. 2000. Seed priming. In seed technology and its biological basis. In Black, M. and J.D. Bewley (Eds). Sheffield Academic press, England. Chapter 9:287-325.

Sadeghi, H., F. Khazaei, L. Yari and S. Sheidaei. 2011. Effect of seed osmopriming on seed germination behavior and vigor of soybean (Glycine max L.). Arpn. J. Agri. Bio. Sci. 6(1): 39-43. 